\title{
Efficacy of different solvent extracts from selected medicinal plants for the potential of antibacterial activity
}

\author{
Fayaz Asad $^{1 *}$, Hussan Ara Begum², Muhammad Hamayun², Reema \\ Hameed $^{2}$, Tabassum Yaseen ${ }^{1}$ and Ajmal Khan ${ }^{3,4}$ \\ 1. Department of Botany, Bacha Khan University Charsadda, KP-Pakistan \\ 2. Department of Botany, Abdul Wali Khan University Mardan, 23200-Pakistan \\ 3. Key Laboratory of Alpine Ecology and Biodiversity, Institute of Tibetan Plateau Research, Chinese Academy of \\ Sciences, Beijing 100101-China \\ 4. University of Chinese Academy of Sciences. No.19A Yuquan Road, Beijing, 100049-China \\ *Corresponding author's email: fayaz.asad79@yahoo.com \\ Citation
}

Fayaz Asad, Hussan Ara Begum, Muhammad Hamayun, Reema Hameed, Tabassum Yaseen and Ajmal Khan. Efficacy of different solvent extracts from selected medicinal plants for the potential of antibacterial activity. Pure and Applied Biology. Vol. 7, Issue 2, pp890-896. http://dx.doi.org/10.19045/bspab.2018.700108

\begin{tabular}{llll}
\hline \hline Received: 26/04/2018 & Revised: 24/06/2018 & Accepted: 26/06/2018 & Online First: 28/06/2018 \\
\hline \hline
\end{tabular}

\section{Abstract}

Six medicinal plants were tested, namely Portulaca oleraceae, Cucumis sativus, Malus baccata, Geranium wallichianum, Monotheca Buxifolia, and Saxifraga flagillaris for antimicrobial activity against five medically important pathogenic bacterial strains, namely Pseudomonas aeruginosa, Staphylococcus aureus, Escherichia coli, Shigella flexneri, and Salmonella typhi. The antimicrobial activities of crude ethanolic extracts and fractions were resolved by using agar well diffusion technique. Our results demonstrated that all the extracts have antimicrobial properties against both Gram-negative and Gram-positive bacteria. The fractions of extracts indicated higher activities contrary to bacterial strains tested with the highest activity observed for n-hexane and followed by dimethyl chloromethane fractions. Among the tested pathogenic bacteria, Staphylococcus aureus was the most vulnerable, while Pseudomonas aeruginosa was less susceptible. In conclusion, ethanolic fractions of Saxifraga flagillaris indicated the highest effectiveness against all the bacterial pathogens tested. Hence, this study ratifies the efficiency of certain extracts to be subjected for natural antimicrobials and further pharmaceutical assessment. Keywords: Antimicrobial activity; Bacteria; Ethanolic extract; Medicinal plants; Pathogens

\section{Introduction}

Most human population (around 70-80\%) of the developing countries, relies on therapeutic plants for primary health care [1]. Medicinal plants possess an ample source of antimicrobial agents. Therefore, several developing countries use them for medical purposes, because they provide a source for many effective and powerful drugs [2].
However, many plant species have been investigated for their anti-microbial characteristics, whereas the majority of them have not been appropriately assessed [2], particularly in Pakistan. Medicinal plants have been proved to be highly effective to treat an extensive range of disease [3]. Contagious diseases frequently occur in Pakistan, therefore, it is essential to explore 
the plant-derived medicines. Mostly, antimicrobial products are imported, due to its less price for the low-income community, which can easily afford them. Thus local medicinal plants can be extensively found and used in Pakistan $[4,5]$.

From primitive times, different plants with antimicrobial properties have been used for curing various pathogenic diseases. Considerable achievements have been observed in the field of herbal medicine, because of less side effects of plants on health [6]. The natural biochemical ingredients of medicinal plants provide positive physiological effects on the human body [7]. Plants harboring antioxidant and antimicrobial potential [8, 9] contain different secondary metabolites like terpenoids, tannins, flavonoids, alkaloids, glycosides, etc., which was observed in vitro to possess antimicrobial properties [10] are valued medicinally. Furthermore, plants with naturally available phytochemicals provide resistance against different diseases [11, 12]. Phytochemical such as proteins, Chlorophyll, and common sugars are considered as primary compounds, and alkaloids, terpenoid, and phenolic are secondary compounds [13].

In developing countries, many studies investigated traditional uses of the medicinal plant [14-22], whereas limited information exists in northwestern Pakistan. Therefore, the present is conducted to identify the antimicrobial activity and efficiency of six different medicinal plant species.

\section{Materials and methods \\ Sample collection}

Plants were sampled from various parts of Khyber Pakhtunkhwa, Pakistan. They were recognized using previous literature [23-25].

\section{Preparation of plant extract}

Plants and their parts were washed through distilled water, air dried, and then grinded to fine powder and kept in airtight bottles. Ethanol was used for the extraction of plant power consecutive three weeks and preserved at $25^{\circ} \mathrm{C}$. Every week, ethanol was evaporated to get the extract from the available filtrate using a rotary evaporator, and the extracts were stored in the refrigerator for further analysis. The extracts were fractionated with dichloromethane, n-hexane, and ethyl-acetate on the basis of the polarity of the solvent. After these processes, we got four extracts, one crude extract and three sub-extracts called fractions of each plant powdered material.

\section{Bacterial Strains}

Gram-positive bacteria such as Staphylococcus aureus, and Gram-negative bacteria such as Escherichia coli, Pseudomonas aeruginosa, Shigella flexneri and Salmonella typhi were analyzed for antibacterial activity.

\section{Media preparation}

Nutrient Broth Medium with was prepared for the growth of bacterial inoculum by dissolving $6.25 \mathrm{~g}$ Luria broth (LB) in $250 \mathrm{ml}$ pure water; $\mathrm{pH}$ was kept neutral and autoclaved. Bacterial culture was injected into media and reserved at $37^{\circ} \mathrm{C}$ for $24 \mathrm{hrs}$ in shaking incubator at $150 \mathrm{rpm}$. By dissolving 40g agar in $1000 \mathrm{ml}$ pure water, LB Agar Medium of $\mathrm{pH} 7.0$ was prepared and autoclaved.

\section{Inoculum preparation}

24-hour old bacteria culture in media (Miller) were mixed combine with normal brine solution till a McFarland turbidity standard $\left[10^{6}\right.$ colony forming unit (CFU) $\left.\mathrm{ml}^{-1}\right]$ was achieved. Then this inoculum was utilized to seed LB Agar Medium.

\section{Agar plates preparation}

LB Agar Medium was transferred into sterilized Petri plates and left to solidify. Following the agar well diffusion technique from a previous publication [26], a sterile cotton swab lawn cultures of the test organisms were done on the agar plates. Per plate, five wells were made by a sterile borer in a sterilized environment. 


\section{Extracts preparation}

$20 \mathrm{mg}$ extracts were dissolved in $10 \mathrm{ml}$ of Dimethylsulfo oxide (DMSO).

Incubation of test solution, and measurement of the zone of inhibition

Test sample solution of $75 \mu \mathrm{l}$ was introduced into labeled well. In every labeled plate samples of extracts were made available, dimethyl sulphoxide (DMSO) (as negative standard) and cefotaxime (as positive standard) in respective wells. After incubation at $37^{\circ} \mathrm{C}$ for 24 and 48 hours, the diameter of clear zones showed no bacterial growth around each well. An average zone of inhibition was calculated in millimeter by repeating the assay three times.

\section{Results}

Antibacterial activity of crude ethanolic extracts

Table 1. Antibacterial activity of crude ethanolic extracts of selected medicinal plants (zone of inhibition in mm)

\begin{tabular}{|c|c|c|c|c|c|}
\hline Plant Name & $\begin{array}{c}\text { Staphylococc } \\
\text { us aureus }\end{array}$ & $\begin{array}{c}\text { Shigella } \\
\text { flexneri }\end{array}$ & $\begin{array}{c}\text { Pseudomonas } \\
\text { aeroginosa }\end{array}$ & $\begin{array}{c}\text { Escherchia } \\
\text { coli }\end{array}$ & $\begin{array}{c}\text { Salmonella } \\
\text { typhi }\end{array}$ \\
\hline $\begin{array}{c}\text { Cucumis } \\
\text { sativus }\end{array}$ & $3.57 \pm 0.83$ & $4.89 \pm 2.47$ & $3.30 \pm 0.35$ & $3.58 \pm 1.21$ & $2.12 \pm 0.12$ \\
\hline $\begin{array}{c}\text { Portulaca } \\
\text { olarecae }\end{array}$ & $26.17 \pm 0.73$ & $14.75 \pm 0.69$ & $12.74 \pm 0.63$ & $15.00 \pm 1.00$ & $20.00 \pm 0.58$ \\
\hline Malus baccata & $11.00 \pm 0.58$ & $12.67 \pm 0.88$ & $13.41 \pm 0.46$ & $12.30 \pm 0.70$ & $11.17 \pm 1.42$ \\
\hline $\begin{array}{c}\text { Saxifraga } \\
\text { flagillaris }\end{array}$ & $14.00 \pm 0.58$ & $11.67 \pm 0.67$ & $14.00 \pm 1.00$ & $17.67 \pm 0.33$ & $14.33 \pm 0.44$ \\
\hline $\begin{array}{c}\text { Geranium } \\
\text { wallichianum }\end{array}$ & $15.67 \pm 1.45$ & $4.67 \pm 1.76$ & $15.63 \pm 0.36$ & $12.00 \pm 0.58$ & $10.46 \pm 0.77$ \\
\hline $\begin{array}{c}\text { Monotheca } \\
\text { buxifolia }\end{array}$ & $16.00 \pm 0.58$ & $12.67 \pm 0.33$ & $14.67 \pm 0.33$ & $15.33 \pm 0.33$ & $15.67 \pm 0.33$ \\
\hline
\end{tabular}

\section{Antibacterial activity of selected plants fractions}

CEEs of each plant were fractionated into three fractions such as n-hexane, dichloromethane (DCM) and ethyl acetate on polarity bases were analyzed for antibacterial activity (Table 2). The extracted fractions of $S$. flagillaris and $M$. buxifolia indicated maximum antimicrobial activity against all the selected pathogenic bacteria. However, $\mathrm{n}$ hexane fractions of Malus baccata ( $M$. baccata) showed the highest antimicrobial
The antibacterial activities of crude ethanolic extracts (CEE) of selected medicinal plants have been listed in (Table 1). The CEEs of Portulaca oleracae (P. oleracae) and Monotheca buxifolia (M. buxifolia) showed a high zone of inhibition against all the selected bacterial strains followed by Saxifraga flagillaris (S. flagillaris). However, CEE of Portulaca oleracae (P. oleracae) showed the highest zone of inhibition such as 26.17 and $20.00 \mathrm{~mm}$ against Staphylococcus aureus ( $S$. aureuss) and Salmonella typhi (S. typhi), respectively. The $S$. flagillaris indicated $17.67 \mathrm{~mm}$ zone of inhibition against Escherchia coli (E. coli), and M. buxifolia indicated $16.00 \mathrm{~mm}$ zone of inhibition against $S$. aureuss. The remaining CEEs were observed less susceptible to selected bacterial strains. 
aeroginosa ( $P$. aeruginosa), respectively. DCM fractions of Portulaca olarecae ( $P$. olarecae) and Geranium wallichianum ( $G$. wallichianum) revealed the antimicrobial activity of $22 \mathrm{~mm}$ against each $S$. aureus and S. flexneri, respectively. M. buxifolia showed the mild activity of almost $20 \mathrm{~mm}$ against all the selected pathogens. Ethyl acetate fraction of $P$. olarecae showed the highest

\section{Table 2. Antibacterial activity of different fractions of selected medicinal plants (zone of} inhibition in $\mathbf{m m}$ )

\begin{tabular}{|c|c|c|c|c|c|c|}
\hline Plant & Fraction & $\begin{array}{c}\text { Staphylococcus } \\
\text { aureus }\end{array}$ & $\begin{array}{l}\text { Shigella } \\
\text { flexneri }\end{array}$ & $\begin{array}{c}\text { Pseudomonas } \\
\text { aeruginosa }\end{array}$ & $\begin{array}{c}\text { Escherchia } \\
\text { coli }\end{array}$ & $\begin{array}{c}\text { Salmonella } \\
\text { typhi }\end{array}$ \\
\hline \multirow{3}{*}{$\begin{array}{l}\text { Cucumis } \\
\text { sativus }\end{array}$} & n-hexane & $18.67 \pm 0.33$ & $11.33 \pm 0.88$ & $10.80 \pm 1.14$ & $17.58 \pm 0.79$ & $23.33 \pm 2.40$ \\
\hline & DCM & $09.95 \pm 0.39$ & $11.95 \pm 0.53$ & $10.85 \pm 2.34$ & $17.25 \pm 0.66$ & $16.60 \pm 1.31$ \\
\hline & $\begin{array}{l}\text { Ethyle } \\
\text { acetate }\end{array}$ & $12.50 \pm 0.76$ & $15.00 \pm 1.53$ & $09.50 \pm 1.04$ & $14.17 \pm 1.17$ & $15.67 \pm 0.33$ \\
\hline \multirow{3}{*}{$\begin{array}{c}\text { Portulaca } \\
\text { olarecae }\end{array}$} & n-hexane & $19.00 \pm 0.58$ & $11.00 \pm 0.58$ & $08.67 \pm 0.88$ & $15.83 \pm 1.01$ & $18.00 \pm 0.58$ \\
\hline & DCM & $22.00 \pm 0.58$ & $08.00 \pm 1.15$ & $11.55 \pm 0.33$ & $13.08 \pm 2.55$ & $10.67 \pm 1.20$ \\
\hline & $\begin{array}{l}\text { Ethyl } \\
\text { acetate }\end{array}$ & $25.67 \pm 0.88$ & $08.33 \pm 1.76$ & $09.00 \pm 1.53$ & $15.50 \pm 1.26$ & $09.67 \pm 1.20$ \\
\hline \multirow{3}{*}{$\begin{array}{l}\text { Malus } \\
\text { baccata }\end{array}$} & n-hexane & $20.67 \pm 0.67$ & $27.25 \pm 0.80$ & $18.67 \pm 0.67$ & $17.67 \pm 0.88$ & $10.67 \pm 0.67$ \\
\hline & $\begin{array}{l}\text { Ethyle } \\
\text { acetate }\end{array}$ & $16.67 \pm 0.33$ & $22.42 \pm 0.96$ & $09.67 \pm 0.33$ & $10.00 \pm 0.00$ & $09.67 \pm 0.33$ \\
\hline & DCM & ND & ND & ND & ND & ND \\
\hline \multirow{2}{*}{$\begin{array}{l}\text { Saxifraga } \\
\text { flagillaris }\end{array}$} & n-hexane & $24.5 \pm 1.32$ & $24.0 \pm 0.58$ & $23.00 \pm 1.53$ & $24.67 \pm 1.45$ & $21.67 \pm 0.88$ \\
\hline & DCM & $23.37 \pm 1.76$ & $24.67 \pm 1.85$ & $23.33 \pm 1.67$ & $23.67 \pm 1.67$ & $25.33 \pm 1.45$ \\
\hline \multirow{3}{*}{$\begin{array}{l}\text { Geranium } \\
\text { wallichian } \\
\quad \text { um }\end{array}$} & n-hexane & $0.67 \pm 0.67$ & $23.67 \pm 1.03$ & $03.33 \pm 3.33$ & $11.00 \pm 0.58$ & $6.98 \pm 2.08$ \\
\hline & DCM & $16.00 \pm 0.58$ & $22.0 \pm 2.52$ & $13.00 \pm 2.52$ & $14.33 \pm 1.20$ & $07.67 \pm 0.33$ \\
\hline & $\begin{array}{l}\text { Ethyle } \\
\text { acetate }\end{array}$ & $21.92 \pm 0.74$ & $18.93 \pm 4.20$ & $01.33 \pm 0.67$ & $\begin{array}{c}11.00 \pm \\
2.802 \\
\end{array}$ & $05.00 \pm 1.155$ \\
\hline \multirow{3}{*}{$\begin{array}{c}\text { Monotheca } \\
\text { buxifolia }\end{array}$} & n-hexane & $21.33 \pm 0.88$ & $21.33 \pm 0.667$ & $20.33 \pm 1.20$ & $20.00 \pm 1.00$ & $20.67 \pm 1.76$ \\
\hline & DCM & $20.00 \pm 0.58$ & $20.33 \pm 1.20$ & $20.67 \pm 1.45$ & $20.00 \pm 0.58$ & $20.00 \pm 0.58$ \\
\hline & $\begin{array}{l}\text { Ethyle } \\
\text { acetate }\end{array}$ & $20.67 \pm 0.33$ & $18.33 \pm 0.88$ & $17.67 \pm 1.20$ & $18.00 \pm 1.15$ & $20.67 \pm 0.68$ \\
\hline
\end{tabular}

$\mathrm{ND}=$ Not Detected, $\mathrm{DCM}=$ dichloromethane

\section{Discussion}

This study demonstrated the antibacterial activity of six medicinal plants against five pathogenic bacteria. The six medicinal plants relating to plants were extracted with $70 \%$ ethanol, while their fractionation was performed on polarity bases with n-hexane, ethyl acetate, and DCM, using agar well diffusion methods (Table $1 \& 2$ ). The type strains tested were a Gram-positive antimicrobial activity of $25.67 \pm 0.88 \mathrm{~mm}$ against $S$. aureus and followed by $M$. baccata and G. wallichianum, which showed the antimicrobial activity of $22.42 \pm 0.96 \mathrm{~mm}$ and $21.92 \pm 0.74 \mathrm{~mm}$ against $S$. flexneri and $S$. aureus, respectively. While $M$. buxifolia showed mild antimicrobial activity against all the selected pathogenic bacteria. 
polarity of the compounds being extracted by each solvent, and in addition to their intrinsic bioactivity, they are capable to dissolve or diffuse in the different media used in the essay [27].

The current results indicated that the CEEs of all tested medicinal plants inhabited the bacterial pathogens tested. However, CEEs of $P$. olarecae exhibited high activity against Gram-positive bacteria i.e. S. aureus, while $S$. flagillaris and $M$. buxifolia exhibited high activity against Gram-negative $E$. coli and $S$. aureus, respectively as compared to rest plants. These results are in line with previous findings [28, 29]. Several studies revealed that Gram-positive bacteria were not vulnerable to plant extract when compared to Gram-positive bacteria [30, 31]. In our data, the low efficiency of CEEs of $C$. sativus on all pathogens tested is in accordance with the previous study, where CEE of Cucumis sativus ( $C$. sativus) have poor activity against Pseudomonas aeruginosa ( $P$. aeruginosa) [32]. Our results suggested that ethanol extraction is the most successful method for extracting the antibacterial metabolites from medicinal plants, as compared to previous methods such as methanol, acetone, and water extraction [33].

Comparatively, CEEs of medicinal plants have low effects on bacterial strains while its fractions showed high effects (Table 2). These results are in accordance with the previous study, where the seed extracts of Praecitrullus fistulosus (Tinda), Cucumis sativa (Cucumber), Lagenaria siceraria (bottle gourd), and Cucurbita pepo (Red pumkin) have been found very active against E. coli, Serratia marcescens, Fusarium oxysporium, Streptococcus thermophilous and Trichoderma reesei [34]. The n-hexane and DCM fractions of $S$. flagillaris depicted the most striking antimicrobial effects against all Gram-positive and Gram-negative bacterial strains compared to the rest extracts. The n-hexane fraction of $M$. baccata and ethyl acetate fraction of $P$. oleracea were highly effective against $S$. flexneri and $S$. aureus, respectively than their other fractions. These findings are in agreement with Fatema and Khanum (2014) [35], who reported high antibacterial activity of ethyl acetate extract against Bacillus subtilis, Bacillus megaterium, Sarcina lutea, $S$. aureus, E. coli, S. typhi, Salmonella paratyphi, Shigella dysenteriae, Shigella boydii, Vibrio parahemolyticus and Vibrio mimicus. Mousavi et al., (2015) [36] found that $P$. oleracea leaves and seeds hydroalcoholic extracts, possess significant antibacterial effects on Streptococcus pneumoniae, Hafnia alvei, Streptococcus pyogenes, Acinetobacter baumannii, Staphylococcus saprophyticus, Enterococcus faecalis, S. aureus, Proteus mirabilis, and Serratia marcescens, and can be a worthy substitute against a drug resistance bacteria. These findings suggested that different CEE fractions of medicinal plants are highly effective against various pathogens.

\section{Conclusion}

The current study identified that the medicinal plants CEEs and their fractions (hexane, dichloromethane and ethyl acetate) demonstrated a varying degree of therapeutic potency. The n-hexane fractions indicated the broad spectrum of antibacterial activities against the tested pathogens. The results of the current study highlight the folkloric anticipation of the studied plants as antimicrobial agents and in therapeutic application. These findings suggest that most active extract can be evaluated for therapeutic antibacterial and further pharmacological assessments.

\section{Authors' contributions}

Conceived and designed the experiments: F Asad, \& HA Begum, Performed the experiments: HA Begum, F Asad, Analyzed the data: F Asad, HA Begum, \& M Hamayun, Contributed materials/ analysis/ tools: $\mathrm{M}$ 
Hamayun, T Yaseen, R Hameed \& A khan. Wrote the paper: F Asad and HA Begum.

\section{Acknowledgments}

The authors would like to thank Dr. Khair Zaman, Department of Chemistry, Abdul Wali Khan University Mardan for providing the chemicals/solvents. We are highly obligated to departmental colleague Dr. Anwer Hussain for their support.

\section{References}

1. Organization WH (2011). Traditional medicine: Fact sheet No. 134, December 2008 Ed.

2. Mahesh B \& Satish S (2008). Antimicrobial activity of some important medicinal plant against plant and human pathogens. World $J$ of Agri Sci 4(5): 839-843.

3. Mukherjee PK, Wahile A, Kumar V, Rai S, Mukherjee K \& Saha B (2006). Marker profiling of botanicals used for hepatoprotection in Indian system of medicine. Drug Information J 40(2): 131139.

4. Shinwari ZK (2010). Medicinal plants research in Pakistan. $J$ of Med Plants Res 4(3): 161-176.

5. Adnan M, Bibi R, Mussarat S, Tariq A \& Shinwari ZK (2014). Ethnomedicinal and phytochemical review of Pakistani medicinal plants used as antibacterial agents against Escherichia coli. Ann of Clin Microbio \& Antimicrobials 13(1): 40.

6. Padulosi S, Leaman D \& Quek P (2002). Challenges and opportunities in enhancing the conservation and use of medicinal and aromatic plants. J of Her, Spic \& Med Plants 9(4): 243-267.

7. Edeoga H, Okwu D \& Mbaebie B (2005). Phytochemical constituents of some Nigerian medicinal plants. Afr $J$ of biotechnology 4(7): 685-688.

8. Kubola J, \& Siriamornpun S (2008). Phenolic contents and antioxidant activities of bitter gourd (Momordica charantia L.) leaf, stem and fruit fraction extracts in vitro. Food Chemistry 110(4): 881-890.

9. Wang S, Melnyk JP, Tsao R, \& Marcone MF (2011). How natural dietary antioxidants in fruits, vegetables and legumes promote vascular health. Food Res International 44(1): 14-22.

10. Dahanukar S, Kulkarni R, \& Rege N (2000). Pharmacology of medicinal plants and natural products. Ind $J$ of pharmacology 32(4): S81-S118.

11. Rios J, \& Recio M (2005). Medicinal plants and antimicrobial activity. $J$ of Ethnopharmacology 100(1-2): 80-84.

12. Hussain I, Khattak MUR, Muhammad Z, Khan N, Khan FA, Ullah Z, \& Haider S (2011). Phytochemicals screening and antimicrobial activities of selected medicinal plants of Khyber Pakhtunkhwa Pakistan. Afr $J$ of Phar and Pharmacology 5(6): 746-750.

13. Baxter H, Harborne JB, \& Moss GP (1998). Phytochemical dictionary: a handbook of bioactive compounds from plants. ed: CRC press.

14. Uddin M, Juraimi AS, Hossain MS, Un A, Ali M \& Rahman M (2014). Purslane weed (Portulaca oleracea): a prospective plant source of nutrition, omega-3 fatty acid, and antioxidant attributes. The Sci World J.

15. Taha H, \& Osman A (2015). Assessment of antioxidant capacity of ethanolic extract of Portulaca oleracea leaves in vitro and in vivo. J of Med Plants Res 9(10): 335-342.

16. El-Sayed M-IK (2011). Effects of Portulaca oleracea L. seeds in treatment of type- 2 diabetes mellitus patients as adjunctive and alternative therapy. J of Ethnopharmacology 137(1): 643-651.

17. Ullah I, Khan JA, Shahid M, Khan A, Adhikari A, Hannan PA, Javed I, Shakeel F \& Farooq U (2016). Pharmacological screening of Monotheca buxifolia (Falc.) A. DC. for antinociceptive, anti-inflammatory and antipyretic activities. BMC Comp \& Altern Medicine 16(1): 273.

18. Qin X, Xing YF, Zhou Z \& Yao Y (2015). Dihydrochalcone compounds isolated from crabapple leaves showed anticancer effects on human cancer cell lines. Molecules 20(12): 21193-21203.

19. Khan SW, Abbas Q, Hassan SN, Khan H, \& Hussain A (2015). Medicinal Plants of Turmic Valley (Central Karakoram National Park), Gilgit-Baltistan, Pakistan. J of Biore Management 2(2): 11. 
20. Ismail M, Hussain J, Khan A-u, Khan AL, Ali L, Khan F-u, Khan AZ, Niaz U, \& Lee IJ (2012). Antibacterial, antifungal, cytotoxic, phytotoxic, insecticidal, and enzyme inhibitory activities of Geranium wallichianum. Evidence-Based Comp \& alter medicine.

21. Martins WB, Rodrigues SA, Silva HK, Dantas CG, Júnior WDL, Cardoso JC, \& Gomes MZ (2016). Neuroprotective effect of Portulaca oleracea extracts against 6hydroxydopamine-induced lesion of dopaminergic neurons. Anais da Academia Brasileira de Ciências 88(3): 1439-1450.

22. Carminative $\mathrm{T}$ (2016). A Review on Antimicrobial Activity of Vegetables, Herbs and Spices Against Cariogenic Bacteria. Res $J$ of Bio 4(4): 12-20

23. Nasir E, Ali S 1970 (1989). Flora of Pak. Nos. 1-190. Department of Botany, Karachi University, Karachi. Pak Agric Res Council Islamabad.

24. Ali SI \& Nasir YJ (1990-1992). Flora of Pakistan. No. 191-193. Department of Botany, University of Karachi, Karachi.

25. Ali, S.I. and M. Qaiser. 1992-2009. Flora of Pakistan. No. 194-217. Department of Botany, University of Karachi, Karachi.

26. Perez C, Pauli M \& Bazerque P (1990). An antibiotic assay by the agar well diffusion method. Acta Biol Med Exp 15(1): 113-115.

27. Prakash P, Gnanaprakasam P, Emmanuel R, Arokiyaraj S, \& Saravanan M (2013). Green synthesis of silver nanoparticles from leaf extract of Mimusops elengi Linn. for enhanced antibacterial activity against multi drug resistant clinical isolates. Coll \& Surf B: Biointerfaces 108: 255-259.

28. Ahmad I, Mehmood Z \& Mohammad F (1998). Screening of some Indian medicinal plants for their antimicrobial properties. $J$ of ethnopharmacology 62(2): 183-193.

29. Lin X, Buff EM, Perrimon N \& Michelson AM (1999). Heparan sulfate proteoglycans are essential for FGF receptor signaling during Drosophila embryonic development. Development 126(17): 3715-3723.

30. Nostro A, Germano M, D'angelo V, Marino A, \& Cannatelli M (2000). Extraction methods and bioautography for evaluation of medicinal plant antimicrobial activity. Lett in app microbiology 30(5): 379-384.

31. Ojala T, Remes S, Haansuu P, Vuorela H, Hiltunen R, Haahtela K, \& Vuorela P (2000). Antimicrobial activity of some coumarin containing herbal plants growing in Finland. $J$ of ethnopharmacology 73(12): 299-305.

32. Khan DA, Hassan F, Ullah H, Karim S, Baseer A, Abid MA, Ubaid M, Khan SA, \& Murtaza G (2013). Antibacterial activity of Phyllantus emblica, Coriandrum sativum, Culinaris medic, Lawsonia alba and Cucumis sativus. Acta Pol Pharm Drug Res 70(5): 855-860.

33. Obeidat M, Shatnawi M, Al-alawi M, AlZu'bi E, Al-Dmoor H, Al-Qudah M, ElQudah J \& Otri I (2012). Antimicrobial activity of crude extracts of some plant leaves. Res J of Microbiology 7(1): 59.

34. Sood A, Kaur P, \& Gupta R (2012). Phytochemical screening and antimicrobial assay of various seeds extract of cucurbitaceae family. Int $J$ of App Bio \& Pharm Tech 3(3): 401-409.

35. Nasrin F (2014). Antimicrobial and cytotoxic activity of ethyl acetate, chloroform and n-hexane extracts of cucumis sativus leaves. The Experiment 21(3):1480-1486.

36. Mousavi SM, Bagheri G, \& Saeidi S (2015). Antibacterial activities of the hydroalcoholic extract of portulaca oleracea leaves and seeds in sistan region, Southeastern Iran. Inter $J$ of Infection 2(2). 